\title{
Biophysical indicators based on satellite images in an irrigated area at the São Francisco River Basin, Brazil
}

\author{
Janice F. Leivas ${ }^{* a}$, Antonio Heriberto de C. Teixeira ${ }^{a}$, Gustavo Bayma-Silva ${ }^{a}$, Carlos Cesar Ronquim ${ }^{\text {a }}$, \\ João Batista Ribeiro da Silva Reis ${ }^{\mathrm{b}}$ \\ ${ }^{a}$ Embrapa Satellite Monitoring, Campinas, São Paulo, Brazil \\ ${ }^{\mathrm{b}}$ EPAMIG, Agricultural Research Company of Minas Gerais, Brazil.
}

\begin{abstract}
The Jaíba Irrigated Perimeter is a large irrigated agriculture area, located in the region Forest Jaíba between the São Francisco and Verde Grande rivers, in the Brazilian semi-arid region. In 2014, irrigators this the region face losses in the interruption of new plantings in irrigated areas due to water scarcity. The objective of this study is combine the model to estimate the Monteith BIO with the SAFER algorithm in the case of obtaining ET, to analyze the dynamics of natural vegetation and irrigated crops in water scarcity period. For application of the model are necessary data from meteorological stations and satellite images. Were used 23 satellite images of MODIS with spatial resolution of $250 \mathrm{~m}$ and temporal 16 days, of 2014 year. For analyze the results, we used central pivots irrigation mask of Minas Gerais state, Brazil. In areas with irrigated agriculture with central pivot, the mean values of BIO over the year 2014 were $88.96 \mathrm{~kg} \cdot \mathrm{ha}^{-1} \cdot \mathrm{d}^{-1}$. The highest values occurred between April 23 and May 8, with BIO $139 \mathrm{~kg} \cdot \mathrm{ha}^{-1} \cdot \mathrm{d}^{-1}$. For areas with natural vegetation, the average BIO was $88.34 \mathrm{~kg} \cdot \mathrm{ha}^{-1} \cdot \mathrm{d}^{-1}$ with lower values in September. Estimates of ET varied with the lowest values of ET observed in natural vegetation $1,91 \pm 1,22 \mathrm{~mm} \cdot \mathrm{d}^{-1}$ and the highest values in irrigated area is observed $3,51 \pm 0,97 \mathrm{~mm} \cdot \mathrm{d}^{-1}$. Results of this study can assist in monitoring of river basins, contributing to the management irrigated agriculture, with the trend of scarcity of water resources and increasing conflicts for the water use.
\end{abstract}

Keywords: irrigated area, SAFER, evapotranspiration, biomass

\section{INTRODUCTION}

In São Francisco River Basin, in the semi-arid Brazilian, was implemented the Irrigated Perimeter of Jaíba. it refers to a great area with agriculture irrigated, located in the region called Forest of the Jaíba, between the rivers São Francisco and Verde Grande. Jaíba is a pole of production of fruits and it is between the biggest of the country in the supply of banana, mango, lemon and tomato, being most of this agricultural produce destined to the foreign market.

The trend of scarcity of water resources, counterpoint to its increasing demand, has caused serious conflicts over water use. The São Francisco river basin, as well as other rivers in Brazil, has been the cause of disputes between irrigators. With low concentration of rainfall, there compromising the perennial water bodies. Thus, the rivers and their tributaries assume a strategic role for urban and rural population. In 2014, the irrigators of the region have faced losses from the interruption of new plantations in irrigated areas due to water scarcity.

The major benefits from the practice of irrigated agriculture should be opposed to the huge consumption of water demanded by irrigation systems that consume about $70 \%$ of derived waters of rivers, lakes and aquifers, requiring effective management to prevent environmental impacts and use conflicts from water. These conflicts are aggravated especially in years of severe drought like 2014 where water scarcity has impacted the demands for human use, energy generation, agriculture, navigation and water transport. In Brazil, the situation becomes more complex due to the

*janice.leivas@embrapa.br; phone 005519 3211-6200; Fax: 005519 3211-6222; www.cnpm.embrapa.br

Remote Sensing for Agriculture, Ecosystems, and Hydrology XVIII, edited by Christopher M. U. Neale, Antonino Maltese, Proc. of SPIE Vol. 9998, 99981N

(C) 2016 SPIE - CCC code: $0277-786 X / 16 / \$ 18 \cdot$ doi: $10.1117 / 12.2241320$

Proc. of SPIE Vol. $999899981 \mathrm{~N}-1$ 
strong dependence of water resources for the generation of electricity, and the spatial distribution of irrigated areas clearly shows the trend of concentration in regions of strong risk of conflict over water use for energy generation and human consumption, such as in São Francisco river basin Grande, Paranaíba and Paranapanema ${ }^{1}$.

In Northern Development Center of Minas Gerais, the basin of the São Francisco River, irrigated crops have replaced the natural vegetation quickly. This land use change highlights the importance of development and tools for quantification of large-scale water productivity parameters applications, enabling dynamic analysis of mixed agrosecosystems ${ }^{2}$.

Considering the effects of land use changes in the irrigation perimeters, it is important to the development and application of tools to quantify water productivity parameters evaluating the dynamics of agricultural systems that occupy irrigated area of Jaiba in the São Francisco River basin.

Evapotranspiration estimation methods generally enable obtaining data on a local scale. However, regions with heterogeneous surfaces with different types of soil and vegetation present quite different evaporation rates, which cannot be perceived in traditional estimation methods. Remote sensing allows the estimation of evapotranspiration over large areas, as a function of biophysical characteristics obtained at each pixel. Another major advantage of the use of satellite imagery in estimating evapotranspiration on a regional scale is that the amount of water consumed in the evapotranspiration process can be detected without the need for quantification of other hydrological parameters, such as soil moisture.

Remote sensing satellite is an efficient tool for estimating water parameters, providing spatial information, location and status of different agroecosystems ${ }^{3}$.

By remote sensing techniques it is possible to obtain surface information without direct measurements obtained by converted energy capture to digital information. Thus, crops information obtained from satellite images, can be coupled to the data of meteorological stations, for the estimation of parameters such as evapotranspiration and biomass on a large scale. To obtain the biophysical parameters was applied agrometeorological-spectral model SAFER (Simple Algorithm For Retrieving Evapotranspiration) using MODIS satellite images (Moderate Resolution Imaging Spectroradiometer) ${ }^{4}$.

The SAFER algorithm (Simple Algorithm For Evapotranspiration Retrieving) was developed and validated with data from field experiments and Landsat images involving natural vegetation and irrigated crops in the Brazilian semi-arid conditions.

The monitoring of actual evapotranspiration by remote sensing in irrigation pivots is an important tool for applications such as agricultural management, water resources monitoring, analysis of water productivity, biomass estimates and agricultural production ${ }^{5}$.

The model proposed for estimating BIO based on global solar radiation (RG) and the development of plant canopies have acceptable accuracy and can be used remotely with any satellite in different ecosystems ${ }^{6}$. Although several studies have already been conducted on large scales, research on the use of models for the combination of ET and BIO are still needed, especially for applications operating on different surfaces with conditions of water scarcity and rational use of water resources.

The aim of this study was to apply SAFER along with satellite images and meteorological data, available by INMET (National Institute of Meteorology) to quantify evapotranspiration and biomass in large scale at irrigated area of São Francisco Basin, to analyze the dynamics of natural vegetation and irrigated crops over a period of water scarcity.

\section{MATERIAL AND METHODS}

Figure 1 represents the location of the irrigated area of Jaiba, in São Francisco River Basin, in the Brazilian semi-arid region. The study area is the São Francisco Basin River, in north of Minas Gerais state, in southern Brazil (Figure 1). According to Koeppen classification, the climate of the study area is Aw, with an average temperature of $23.0^{\circ} \mathrm{C}$ and average annual rainfall of $938 \mathrm{~mm}$. The analysis period was the year of 2014. Meteorological data were used air temperature, relative humidity, wind and solar radiation stations provided by Brazilian National Institute of Meteorology (INMET), and processed MODIS (Moderate Resolution Imaging Spectroradiometer) data, product MOD13Q1, reflectance bands $1\left(\alpha_{1}\right)$ and $2\left(\alpha_{2}\right)$, with a spatial resolution of $250 \mathrm{~m}$ and a temporal resolution of 16 days. The SAFER ${ }^{7}$ (Simple Algorithm for Retrieving Evapotranspiration) model was applied to obtain evapotranspiration and biomass rates. 


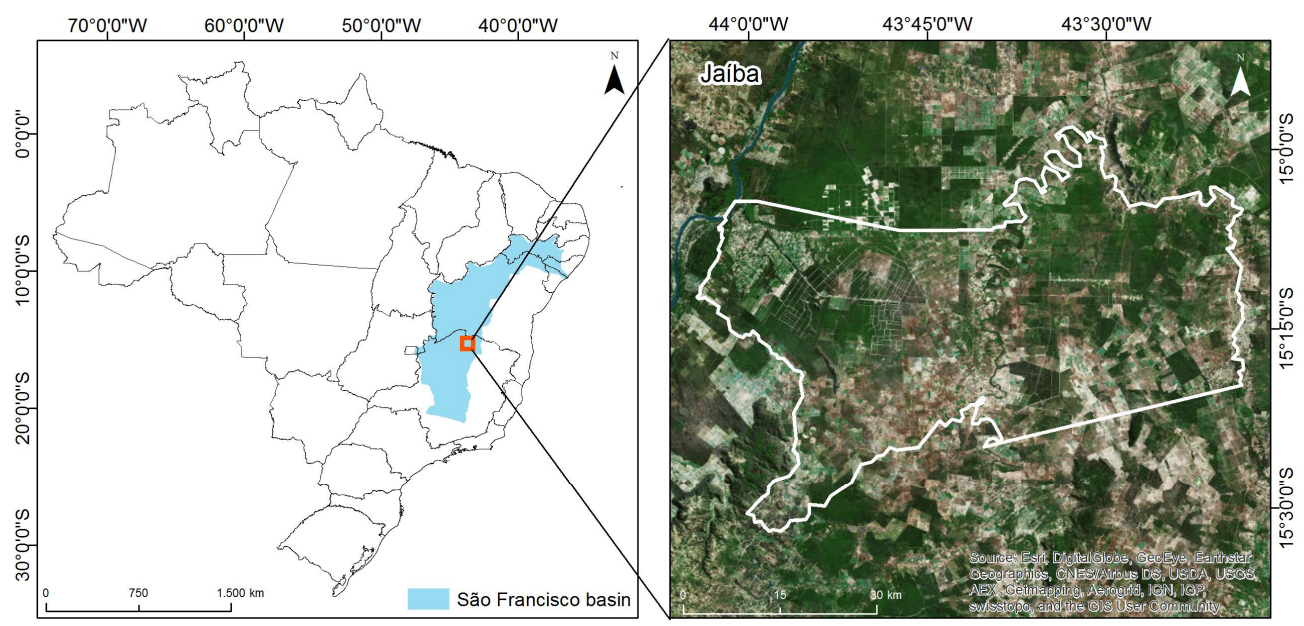

Figure 1. Location of the study area, highlighting the San Francisco River Basin and the perimeter Jaíba Irrigation, Minas Gerais state, Brazil.

For model application is necessary agrometeorological data and satellite images. Were used 23 satellite images of MODIS (Moderate Resolution Imaging Spectroradiometer) with spatial resolution of $250 \mathrm{~m}$ and temporal 16 days, of 2014 year have been used. To extract the results, we used mask central pivots irrigation of Minas Gerais, available by Embrapa Maize and Sorghum. The methodology used to obtain the areas with center pivot was by visual identification, based on the mosaic composed of satellite images Landsat 8 -OLI / TRS $2013^{8}$.

Daily weather data of global solar radiation were used (RG), air temperature (Ta) and reference evapotranspiration (ETO), averages were calculated from 16 days to correspond to the temporal resolution of MODIS images for the purpose of obtaining parameters of evapotranspiration (ET) and biomass (BIO) on a large scale. The parameters calculated by remote sensing for input in the models were the surface albedo $(\alpha 0)$, the surface temperature (To) and the NDVI. The ET was obtained by applying the algorithm SAFER ${ }^{7}$.

For the surface albedo $\left(\alpha_{0}\right)$ calculations the reflectance values from the bands 1 and 2, extracted from the MODIS product MOD13Q1, with a time scale of 16 days were used, insuring a spatial resolution of $250 \mathrm{~m}$ for all water productivity parameters ${ }^{9}$ :

$$
\alpha_{0}=\mathrm{a}+\mathrm{b} \alpha_{1}+\mathrm{c} \alpha_{2}
$$

where $\alpha_{1}$ and $\alpha_{2}$ are the reflectance values for the bands 1 and 2 from MODIS satellite measurements, and $a, b$, and $c$ are regression coefficients obtained comparing these measurements with field data ${ }^{10}$, thus including the atmospheric effects through the radiation path. Their values found for the Brazilian semiarid conditions were, respectively, 0.08 , 0.41 and 0.14 .

For the surface temperature $\left(T_{0}\right)$, the thermal radiation balance equation was applied ${ }^{11}$ :

$$
\mathrm{T}_{\mathrm{S}}=\sqrt[4]{\frac{\mathrm{R}_{\mathrm{G}}-\alpha_{0} \mathrm{R}_{\mathrm{G}}+\varepsilon_{\mathrm{A}} \sigma \mathrm{T}_{\mathrm{a}}^{4}-\mathrm{R}_{\mathrm{n}}}{\varepsilon_{\mathrm{S}} \sigma}}
$$

where $R_{G}$ and $T_{a}$ are respectively the daily values of the incident solar radiation and mean air temperature at the agrometeorological stations, $\mathrm{Rn}$ is the daily net radiation, $\varepsilon_{\mathrm{A}}$ and $\varepsilon_{\mathrm{S}}$ are respectively the atmospheric and surface emissivity, and $\sigma$ is the Stefan-Boltzmann constant $\left(5.67 \times 10^{-8} \mathrm{~W} \mathrm{~m}^{-2} \mathrm{~K}^{-4}\right)$.

$\varepsilon_{\mathrm{S}}$ and $\varepsilon_{\mathrm{A}}$ were calculated as follows ${ }^{12-13}$ :

$$
\begin{aligned}
& \varepsilon_{\mathrm{S}}=\mathrm{a}_{\mathrm{S}} \ln \mathrm{NDVI}+\mathrm{b}_{\mathrm{S}} \\
& \varepsilon_{\mathrm{A}}=\mathrm{a}_{\mathrm{A}}+\left(\ln \tau_{\mathrm{S}}\right)^{\mathrm{b}_{\mathrm{A}}}
\end{aligned}
$$

where $\tau$ is is the short-wave transmissivity calculated as the ratio of $R_{G}$ to the incident solar radiation at the top of the atmosphere, and $a_{S}, b_{S}, a_{A}$ and $b_{A}$ are regression coefficients taken as $0.06,1.00,0.94$ and $0.10^{13}$. 
Daily $R_{n}$ can be described by the 24-hour values of net shortwave radiation, with a correction term for net longwave radiation for the same time-scale ${ }^{13}$ :

$$
\mathrm{R}_{\mathrm{n}}=\left(1-\alpha_{0}\right) \mathrm{R}_{\mathrm{G}}-\mathrm{a}_{1} \tau_{\mathrm{sw}}
$$

where $a_{l}$ is the regression coefficient of the relationship between net long wave radiation and $\tau_{\mathrm{sw}}$ on a daily scale. Because of the thermal influence on longwave radiation via the Stephan Boltzmann equation, a previous study investigated whether the variations of the al coefficient from Eq. 6 could be explained by variations in 24 hours Ta ${ }^{13}$ :

$$
\mathrm{a}_{1}=\mathrm{dT}_{\mathrm{a}}-\mathrm{e}
$$

where $d$ and e are regression coefficients found to be 6.99 and 39.93 respectively for the Brazilian Northeast conditions. The SAFER algorithm is used to model the instantaneous values of the ratio ET/ETO, which is then multiplied by ETO from the weather stations to estimate the daily ET large-scale values:

$$
\frac{\mathrm{ET}}{\mathrm{ET}_{0}}=\left\{\exp \left[\mathrm{f}+\mathrm{g}\left(\frac{\mathrm{T}_{0}}{\alpha_{0} \mathrm{NDVI}}\right)\right]\right\}
$$

where $\mathrm{ET}_{0}$ is the map of reference evapotranspiration from weather stations calculated by the Penman-Monteith method and $f$ and $g$ are the original regressions coefficients, 1.9 and $-0.008\left[{ }^{13}\right]$, respectively.

The evaporative fraction (Ef) is included to take into account the soil moisture effects, and is defined as the latent heat flux $(\lambda E)$ divided by the available energy, which in turn is the difference between $\mathrm{Rn}$ and soil heat flux $(\mathrm{G})$ :

$$
\mathrm{E}_{\mathrm{f}}=\frac{\lambda \mathrm{E}}{\mathrm{R}_{\mathrm{n}}-\mathrm{G}}
$$

where $\lambda E$ is obtained by transforming ET into energy units, with all energy terms considered in $M J \mathrm{~m}^{-2} \mathrm{~d}^{-1}$ in the SAFER algorithm.

For the daily $\mathrm{G}$ values, the equation was used ${ }^{12}$ :

$$
\frac{\mathrm{G}}{\mathrm{R}_{\mathrm{n}}}=\mathrm{a}_{\mathrm{G}} \exp \left(\mathrm{b}_{\mathrm{G}} \alpha_{0}\right)
$$

where $\mathrm{a}_{\mathrm{G}}$ and $\mathrm{b}_{\mathrm{G}}$ are regression coefficients found to be 3.98 and -25.47 respectively.

RG daily values were used to estimate the large scale Photosynthetically Active Radiation (PAR) for the daily time-scale:

$$
\mathrm{PAR}=\mathrm{hR}_{\mathrm{G}}
$$

where $h=0.44$ is the constant of the regression equation found under the Brazilian conditions that reflects the portion of RG that can be used by leaf chlorophyll for photosynthesis ${ }^{14}$.

The values of Absorbed Photosynthetically Active Radiation (APAR) can be approximated directly from PAR:

$\mathrm{APAR}=\mathrm{f}_{\mathrm{PAR}} \mathrm{PAR}$

The factor fPAR is estimated from the NDVI values ${ }^{15,16}$ :

$$
\mathrm{f}_{\text {PAR }}=\mathrm{iNDVI}+\mathrm{j}
$$

The coefficients $i$ and $j$ of 1.257 and -0.161 , respectively, reported for a mixture of arable crop types ${ }^{16}$ were considered and the $\mathrm{BIO}$ is quantified as:

$\mathrm{BIO}=\varepsilon_{\max } \mathrm{E}_{\mathrm{f}} \mathrm{APAR} 0.864$

where $\varepsilon$ max is the maximum light use efficiency, which depends on whether the vegetation is c3 or c4 species, and 0.864 is a unit conversion factor ${ }^{14-15}$.

Subsequently, the ET and BIO average values of natural vegetation and irrigated areas were extracted according to the pivots mask of Minas Gerais State, available for Embrapa Maize and Sorghum. 


\section{RESULTS AND DISCUSSION}

In Figure 2, there is a temporal variability of meteorological data provided by INMET (National Institute Meteorological) along the 2014 year, for 16 days period being observed period with low rainfall, occurring high air evaporative demand due to high solar radiation and $\mathrm{ET}_{0}$ values.

Highest values of both solar radiation (Rg) and $\mathrm{ET}_{0}$ occurred in April to October period (Day of year 113 and 335/2014). Rg this period reached rates above $24 \mathrm{MJ} \mathrm{m}^{-2} \mathrm{~d}^{-1}$, causing high rates of $\mathrm{ET}_{0}$ above $96 \mathrm{~mm} \mathrm{~mm}$ for the period of 16 days. Low rain rates occurred in few days and concentrated along the year being interspersed with long periods of drought and high temperature, characteristic of year-occurrence of El Niño event ${ }^{17}$. These weather conditions have favored drought occurrence. Longer periods without the presence of clouds with high atmospheric demand and high values of solar radiation. The standard rainfall for the study area is 938 mm.year ${ }^{-1}$ and in 2014 the rainfall was only $413.4 \mathrm{~mm}$, causing severe water deficit for the region. In the 2014 Brazil has been affected by drought. This fact can be noted the rainfall and solar radiation distribution along the 2014 year. Many problems happened for farmers using water from small reservoirs, streams or creeks and rivers with low flow rate, irrigation, facing problems such as decreased productivity. The banana productivity of municipality of Jaiba 2014 was around $25000 \mathrm{~kg}^{-h^{-1}}$ (IBGE /PAM).

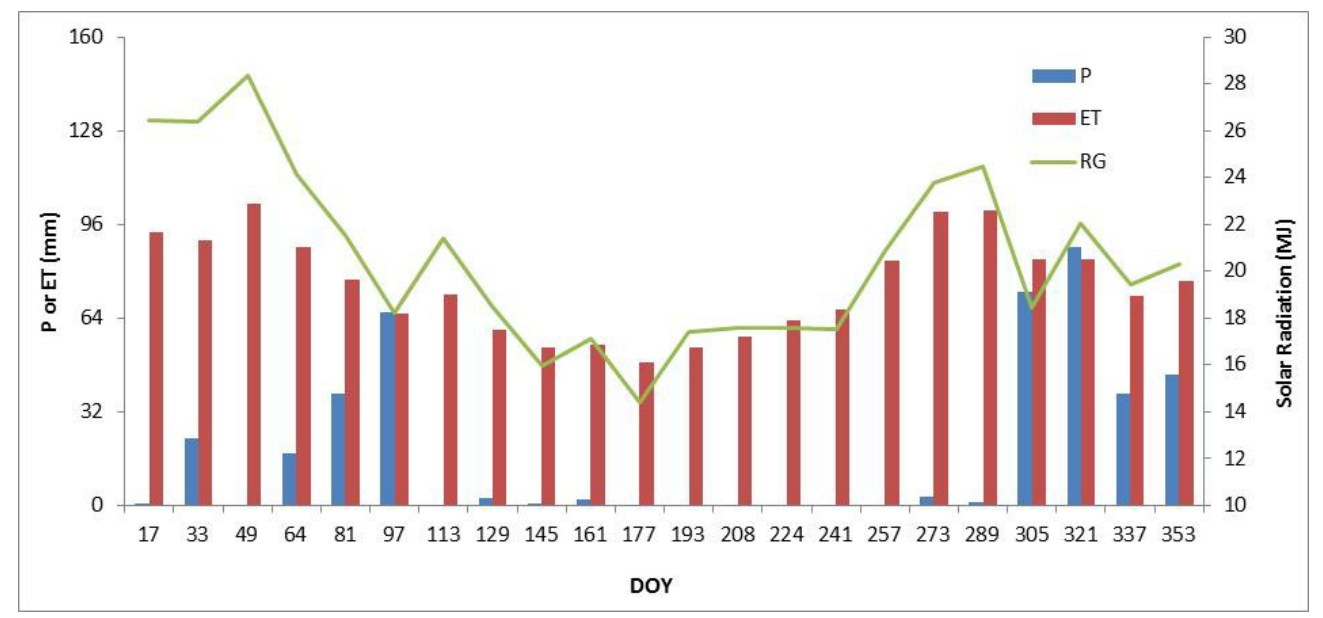

Figure 2. Total evapotranspiration reference (ET) and precipitation (P) Average Solar radiation global (Rg), during the year 2014 in north of Minas Gerais state, Brazil, for 16 days interval.

Figures 3 and 4 represent the spatial distribution of evapotranspiration (ET) and biomass (BIO) to two distinct periods (DOY 113 and 353) of the year 2014, covering the area of irrigated area of Jaiba, in the São Francisco Basin, from occurrence of water scarcity. In Figure 3, the ET analysis in the period between April 23 and May 8, 2014 (DOY 113) observed the difference between irrigation vegetation response (red tones), with the pixels of higher values representing the areas with central pivots, reaching ET values higher than $6 \mathrm{~mm} \cdot \mathrm{d}^{-1}$ and in the areas of natural vegetation (blue) and were around $1 \mathrm{~mm} \cdot \mathrm{d}^{-1}$.The lower average values of evapotranspiration were observed in natural vegetation $\left(1.91 \pm 1.22 \mathrm{~mm} \cdot \mathrm{d}^{-1}\right)$ and greatest values of ET in irrigated area $\left(3.51 \pm 0.97 \mathrm{~mm} \cdot \mathrm{d}^{-1}\right)$.

In December (Day of the year 353) due to the occurrence of rainfall from November, the natural vegetation responds similarly to irrigate areas, reducing the contrast between the surfaces analyzed. It is observed that evapotranspiration rates increased from November 2014. In areas without irrigation, ET is lower and has less variation due to the conversion of energy available for heating the air in the driest periods of the year. During the dry season, the natural vegetation converts part of the energy available in sensible heat $(\mathrm{H})$, while irrigated crops have high values $\mathrm{ET}^{18}$. 

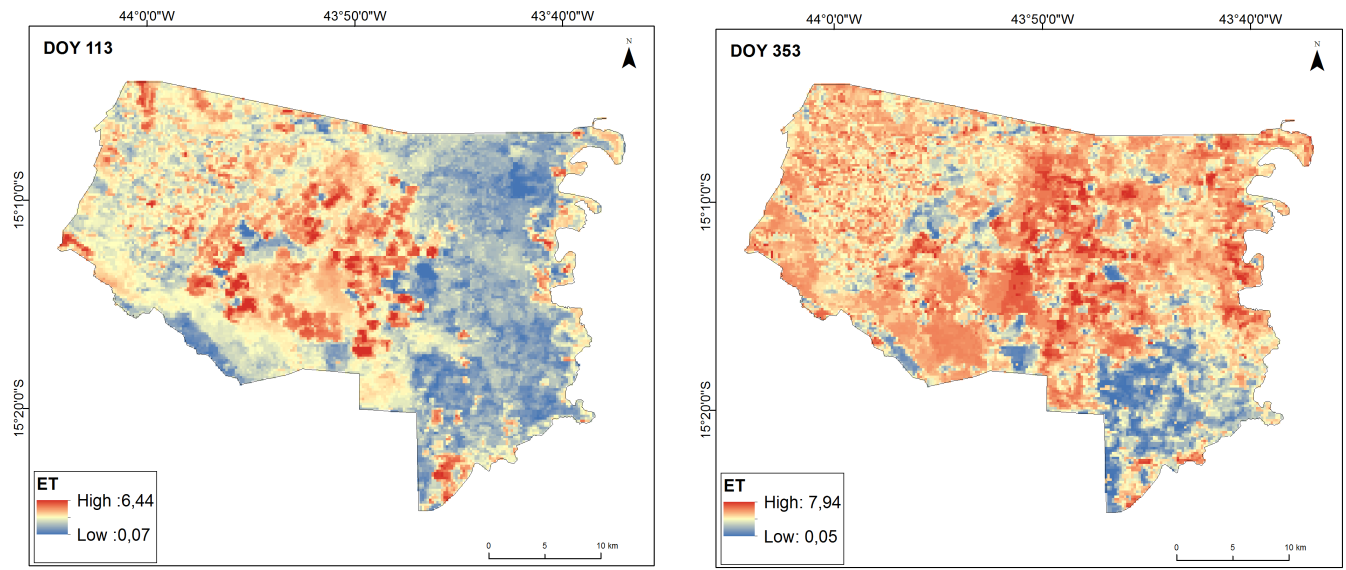

Figure 3. Spatial distribution of daily average evapotranspiration $(\mathrm{mm})(\mathrm{ET})$ during the year 2014 for natural vegetation and irrigated crop and areas, in Jaíba Perimeter Irrigated, São Francisco Basin River.
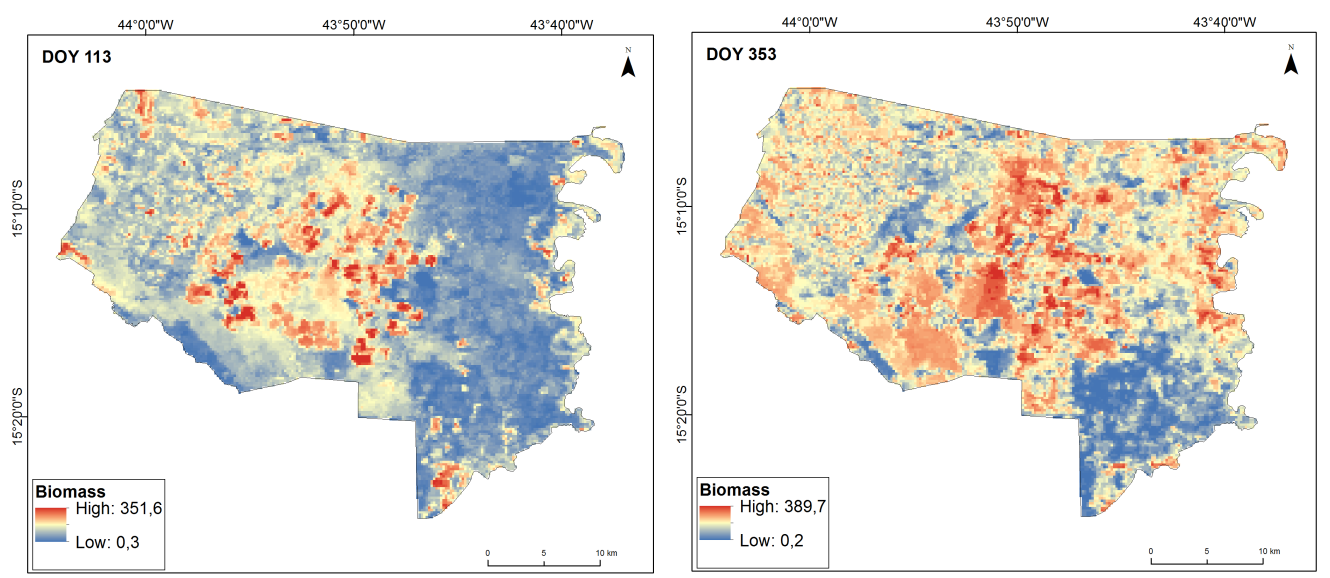

Figure 4. Spatial distribution of daily average $\mathrm{BIO}\left(\mathrm{kg} \cdot \mathrm{ha} \mathrm{a}^{-1} \cdot \mathrm{d}^{-1}\right)$ during the year 2014 for natural vegetation and irrigated crop and areas, in Jaíba Perimeter Irrigated, São Francisco Basin River. (DOY - Day of the year).

In Figure 4, the variation between irrigated and natural vegetation areas is observed in the dry season (Day of the year 113). The average values of BIO in irrigated areas were $88.96 \pm 55.6 \mathrm{~kg} \cdot \mathrm{ha}^{-1} . \mathrm{d}^{-1}$ between $23 \mathrm{April}$ and $8 \mathrm{May}$ 2014 (Day of the year 113). In natural vegetation areas, the average BIO was $56.41 \pm 54.24 \mathrm{~kg} \mathrm{ha}^{-1} . \mathrm{d}^{-1}$, demonstrating large spatial variation.

It is observed dependence between BIO and the water conditions (Figure 2), for the year 2014 was observed high solar radiation and low rainfall, causing contrast between natural vegetation and irrigated crops. The daily average $\mathrm{BIO}$ in irrigated areas was daily values above $139 \mathrm{~kg} \mathrm{ha}^{-1} \cdot \mathrm{d}^{-1}$. The values of BIO both ecosystems are sensitive to the spatial distribution of precipitation and soil moisture ${ }^{19}$.

Many applications of MODIS satellite images combined with meteorological data were used to obtain BIO. In the Sub medium São Francisco basin river, Brazil, BIO estimates perform using Landsat to obtain on large-scale water productivity ${ }^{20}$.

Figure 5 shows temporal distribution of average ET and BIO in irrigated area and natural vegetation for specific periods of 16 days. There is higher ET mean values in irrigated areas (above $3.5 \mathrm{~mm} \mathrm{~d}^{-1}$ ) natural vegetation (below 2.5 mm.d-1), in the dry period (between April and May 2014 (DOY 113) and November / December (DOY 353). This occurs because in the natural vegetation (caatinga), most of the available energy is used for sensible heat flux, heating the air ${ }^{3}$. 


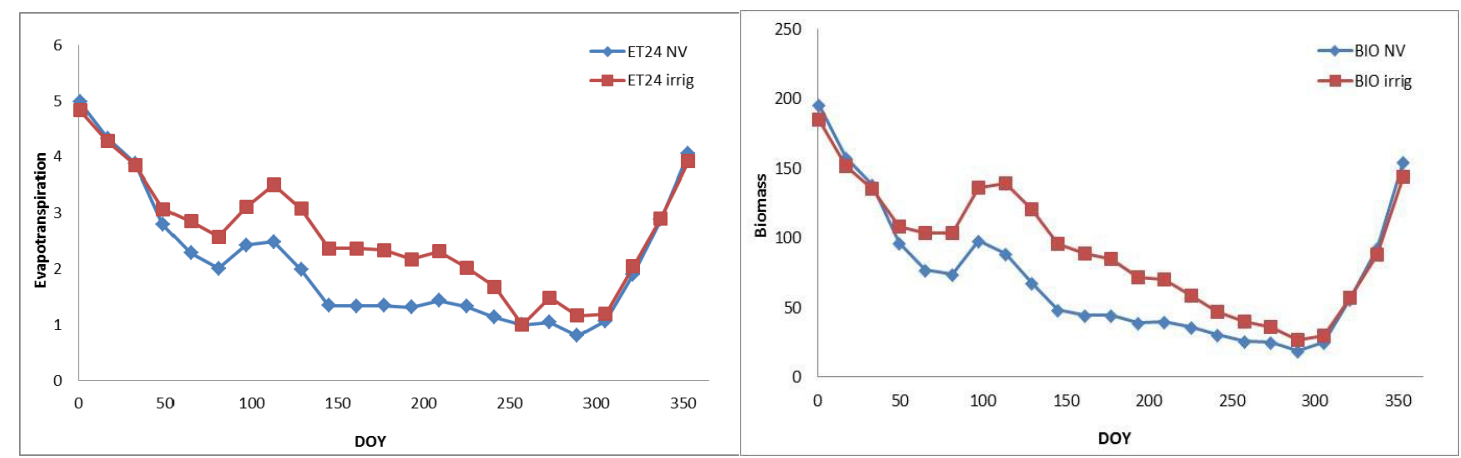

Figure 5. Temporal distribution of average ET and BIO in irrigated area and natural vegetation for specific periods of 16 days.

The lowest average evapotranspiration values were observed in natural vegetation area $\left(1.91 \pm 1.22 \mathrm{~mm} . \mathrm{d}^{-1}\right)$ and the highest ET values in irrigated area $\left(3.51 \pm 0.97 \mathrm{~mm} . \mathrm{d}^{-1}\right)$. Comparing the differences in average ET of irrigated crops and natural vegetation, it is clear that the incremental evapotranspiration, due to presence of center pivots.

In irrigated areas the average BIO values over the year 2014 were $88.96 \mathrm{~kg} \mathrm{ha}^{-1} \mathrm{~d}^{-1}$ and standard deviation of $55.60 \mathrm{~kg} \mathrm{ha}^{-1} \mathrm{~d}^{-1}$. The highest values occurred between April 23 and May 8, with BIO $139 \mathrm{~kg} \cdot \mathrm{ha}^{-1}$. $\mathrm{d}^{-1}$. For areas with natural vegetation, the average BIO was $88.34 \mathrm{~kg} \cdot \mathrm{ha}^{-1} . \mathrm{d}^{-1}$ (standard deviation of $57.27 \mathrm{~kg}$.ha ${ }^{-1}$. $\mathrm{d}^{-1}$ ) with lower values in September. The low values of BIO natural vegetation due to the severe drought occurred in 2014, combined with the EI Niño phenomenon, which caused rainfall decrease in the semi-arid Brazilian.

According to the IBGE (Brazilian Institute of Geography and Statistics) the Municipal Agricultural Production $(\mathrm{PAM})^{21}$, the average yield of banana production in Jaíba in 2014 was $25352 \mathrm{Kg}^{2} \mathrm{ha}^{-1}, 30 \%$ lower than the previous year as well as in crops lemon, mango, among The water consumption of irrigated crops in the Brazilian semi-arid conditions exceed for the species of the Caatinga in dry period, causing an increase biomass (BIO) and the actual evapotranspiration (ET) on a large scale ${ }^{20}$.

The severe drought which occurred in 2014 had an impact on the amount of pivots with two production cycles in the dry season, however, the impact on the area planted was lower due to the use of large equipment ${ }^{22}$. In a study in the same region, found ETC maximum daily values between 6.6 and $7.6 \mathrm{~mm} . \mathrm{d}^{-1}$, coinciding with the rainfall (October to March). The authors emphasize the significance of knowledge on maximum daily water requirement and annual total, enabling scale irrigation projects and estimate the total volume of water removed to supply their water requirements, fundamental information on water resources management and planning irrigation projects ${ }^{23}$

Applying digital image processing techniques, is possible to retrieve evapotranspiration estimations with median spatial resolutions and high temporal frequency, allowing monitoring the temporal evolution of the actual evapotranspiration in central pivots 5 .

Many studies emphasize that the efficient use of water resources assist the quality and quantity of water available and is essential for sustainable and potential expansion of irrigated agriculture ${ }^{24}$.

In studies for irrigated areas monitoring in real time, it was observed that higher concentration of irrigated area in the months of May and June, with strong decrease in the second semester due to the drought which occurred in 2014. The authors observed an increased number of equipment fallowed (idle) in the year 2014 and the same occurs concerning number of crops made annually and in 2013 most of the centers received crops twice during the dry season while in 2014 the producers opted predominantly to only one crop. Due to severe drought in 2014, especially in the second semester, the use of irrigation was quite suppressed ${ }^{1}$.

As well as in the São Francisco Basin, in the basin of the Rio San Marcos, the use of irrigation center pivot tends to be intense in the months of May and June and the severe drought which occurred in 2014 had an impact on the amount of pivots with two production cycles in the dry season, however, the impact on the area planted was lower due to the use of large equipment.

The Riachao drainage basin, which is in inserted in the geographic region of Minas Gerais state, Brazil, has become the platform for disputes between irrigators and farmers for the land use and water. The concentration of rainfall interfer the maintenance of perennial water bodies, and that basin plays an important role in the quality life of the surrounding region. From the results one can see the intrinsic relationship between the disordered forms of land 
use and availability of water downstream in the river basin, which has created conflicts between irrigators, concentrated in the upper basin and small producers in the prevailing medium and low river ${ }^{25}$.

The use of meteorological data with MODIS satellite images, it was possible to monitor and evaluate the biophysical indicators in areas with land use change, at intervals of 16 days. In Jaiba irrigated perimeter there is significant variation in ET and BIO values over the year, in a year of water scarcity, to assist in decision in real time.

\section{CONCLUSIONS}

In times of water scarcity, biophysical parameters monitoring is critical to rational use of water resources, assisting in the irrigated areas monitoring in real time by using MODIS images and meteorological station data. The SAFER model proved effective for estimating the biophysical parameters like evapotranspiration and biomass production in irrigated areas in São Francisco Basin River.

Results of this study can assist in monitoring of river basins, contributing to the management irrigated agriculture, with the trend of scarcity of water resources and increasing conflicts for the water use. . The results can contribute rational use of water resources for irrigation purposes.

\section{ACKNOWLEDGEMENTS}

The National Council for Scientific and Technological Development (CNPq) is acknowledged for the financial support to a project on large-scale water productivity in Brazil.

\section{REFERENCES}

[1] Guimarães, D.P. Landau, E.C. “Monitoramento da agricultura irrigada em tempo real” Anais XVII SBSR, INPE, 2015.

[2] Teixeira, A.H. de C., Andrade, R.G., Leivas, J.F., Victoria, D.C., Bolfe, E.L. "Balanço de energia e produtividade da água em larga escala: caracterização, modelagem e aplicação no norte de Minas Gerais" Informe Agropecuário, v.36, n. 285, p.101-108, 2015.0100-3364, 2015.

[3] Teixeira, A.H. de C., Determining regional actual evapotranspiration of irrgated crops and natural vegetation in the São Francisco river basin (Brazil) using remote sensing an Penman-Monteith equation. Remote Sensing, v.2, n.5, p.1287-1319, May 2010.

[4] Teixeira, A.H. de C., Scherer-Warren, M., Hernandez, F.B.T., Andrade, R.G., Leivas, J.F. "Large-Scale Water Productivity Assessments with MODIS Images in a Changing Semi-Arid Environment: A Brazilian Case Study," Rem.Sens. 55783-5804 (2013).

[5] Morris, S.W.; Rodrigues, L.N. Estimativa da evapotranspiração real por sensoriamento remoto: procedimento e aplicação em pivô central , ISSN 2176-509X, Boletim de Pesquisa e Desenvolvimento, 35p., 2013.

[6] Bastiaanssen, W.G.M., Ali, S. A new crop yield forecasting model based on satellite measurrements applied across the Indus basin, Pakistan. Agriculture, Ecosystems \& Environment, v.94, n.3, p.321-340, Mar.2003.

[7] Teixeira, A. H. de C. Modelling evapotranspiration by remote sensing parameters and agro-meteorological stations. In: Remote Sensing and Hydrology (ed. by C. M. U. Neale \& M. H. Cosh), 154-157. IAHS Publ. 352. IAHS Press, Wallingford, UK (2012).

[8] Guimarães, D.P. Landau, E.C. "Mapeamento das Áreas Irrigadas por Pivôs Centrais no Estado de Minas Gerais" Boletim de pesquisa Embrapa Milho e Sorgo, 1679-0154, 2011.

[9] Valiente, J. A., Nunez, M., Lopez-Baeza, E., Moreno, J. F. "Narrow-band to broad-band conversion for Meteosat visible channel and broad-band albedo using both AVHRR-1 and -2 channels". Int. J. Rem. Sens. 16, 1147-1166 (1995). 
[10] Teixeira, A.H. de C., Hernandez, F.B.T., Lopes, H.L., Scherer-Warren, M., Bassoi, L.H. A Comparative Study of Techniques for Modeling the Spatiotemporal Distribution of Heat and Moisture Fluxes in Different Agroecosystems in Brazil. In: George G. Petropoulos. (Org.). Remote Sensing of Energy Fluxes and Soil Moisture Content. 1ed.Boca Raton, Florida: CRC Group, Taylor and Francis, 169-191 (2014a).

[11] Teixeira, A.H. de C., Hernandez, F.B.T., Andrade, R.G., Leivas, J.F., Victoria, D. de C., Bolfe, E.L. Irrigation performance assessments for corn crop with Landsat images in the São Paulo state, Brazil. Proc. INOVAGRI $739-748$ (2014b).

[12] Teixeira, A. H. de C. "Determining regional actual evapotranspiration of irrigated and natural vegetation in the São Francisco river basin (Brazil) using remote sensing an Penman-Monteith equation," Rem. Sens., 2, 1287-1319 (2010).

[13] Teixeira, A.H. de C., Hernandez, F.B.T., Lopes, H.L., Scherer-Warren, M., Bassoi, L.H. A Comparative Study of Techniques for Modeling the Spatiotemporal Distribution of Heat and Moisture Fluxes in Different Agroecosystems in Brazil. In: George G. Petropoulos. (Org.). Remote Sensing of Energy Fluxes and Soil Moisture Content. 1ed.Boca Raton, Florida: CRC Group, Taylor and Francis, 169-191 (2014a).

[14] Teixeira, A.H. de C. Water productivity assessments from field to large scale: a case study in the Brazilian semi-arid region; LAP Lambert Academic Publishing: Saarbrücken, Germany, 226p. (2009).

[15]Teixeira, A. H. de C., Bastiaanssen, W. G. M., Ahmad, M-ud-D, Bos, M. G. "Reviewing SEBAL input parameters for assessing evapotranspiration and water productivity for the Low-Middle São Francisco River basin, Brazil Part B: Application to the large scale," Agric. For. Meteorol. 149, 477-490 (2009).

[16] Khandelwal, M.K. Meteorological aspects of wet season rice cultivation in Sunderbans region, India. International Rice Research Newsletter, v.16, p.25-26, 1991.

[17] Silva, D.F.; Alcântara, C.R. Déficit Hídrico na Região Nordeste: Variabilidade Espaço-Temporal. UNOPAR Cient. Exatas Tecnol., , Londrina, v. 8, n. 1, p.45-51, Nov. 2009

[18] Teixeira, A.H. de C., Bastiaanssen, W.G.M., Ahmad, M.D., Moura, M.S.B., Bos, M.G. Analysis of energy fluxes and vegetation-atmosphere parameters in irrigated and natural ecosystem of semi-arid Brazil, Journal of Hidrology, v.362, p. 110-127, 2008.

[19] Claverie, M.; Demarez, V.; Duchemin, B.; Hagolle, O.; Ducrot, D.; Maraissicre, C.; Dejuoux, J.F.; Huc, M.; Keravec, P.; Béziat, P.; Fieuzal, R.; Ceschia, E.; Dedieu. G. Maize and sunflower biomass estimation in southwest France using spatial and temporal resolution remote sensing data. Remote Sensing of Environment 124, 884-857, 2012.

[20] Teixeira, A.H. de C. Water productivity assessments from field to large scale: a case study in the Brazilian semi-arid region; LAP Lambert Academic Publishing: Saarbrücken, Germany, 226p. (2009).

[21]IBGE, Instituto Brasileiro de Geografia e Estatistica. Produção Agrícola Municipal. http://www.sidra.ibge.gov.br/bda/. Access: 10 mar. 2016.

[22] Guimarães, D. P.; Landau, E. C. Mapeamento das áreas irrigadas por pivôs centrais no Estado de Minas Gerais Sete Lagoas : Embrapa Milho e Sorgo, 2011. 23 p. : il. -- (Boletim de Pesquisa e Desenvolvimento / Embrapa Milho e Sorgo, ISSN 1619-0154; 40

[23] Freitas, W. da S.; Ramos, M. M.; Costa, S. L. Demanda de irrigação da cultura da banana na bacia do Rio São Francisco, R. Eng. Agríc e Ambiental, v.12, n.4, p.343-349, 2008.

[24] Landau, E. C.; Guimarães, D. P.; Souza, D. L. de .Caracterização ambiental das áreas com agricultura irrigada por pivôs centrais na região do Matopiba - Brasil, Sete Lagoas : Embrapa Milho e Sorgo, $2014 . \quad 43$ p. : il. -- (Boletim de Pesquisa e Desenvolvimento / Embrapa Milho e Sorgo, ISSN 1679-0154; 99).

[25] Leite, M.; Leite, M.R.; Clemente, C. M. S. Land use and water conflict at upper Riachao river in northern of Minas Gerais: an analysis aided by geospatial technology. Rev Geografica Academica, Jan, 2010, Vol.4(1), p.46(10). 